Editorial

\title{
The social determinants of health - how migrants and the Roma are effected by the pandemic
}

\author{
Bernadett M. Varga \\ Public Health Adviser - Migrants \& Ethnic Minorities, Candidate of the United Nations Human Rights Council Special Rapporteur on the right to health \\ mandate, 2020, former Scientific Collaborator of the Université Catholique de Louvain, Belgium
}

Ethnic minorities and migrants are among the most vulnerable groups in our society, yet they are often left helpless and deprived of proper access to healthcare services.

Most European public hospitals are not ready to meet the specific needs of migrants (neither documented, nor undocumented). The hospital staff has not received trainings and cannot ensure the presence of an interpreter. A study (Chauvin et al., 2015) on the access to healthcare for people facing multiple health vulnerabilities across eleven countries found that $54.8 \%$ of migrants needed an interpreter when visiting a health facility. A total of $78 \%$ of the respondents were third country nationals and $15.6 \%$ of them were migrant EU citizens. However, ethnic data collection in accordance with the Data Protection Directive (Directive 95/46/EC [1995] OJ L281/31) prohibits ethnic censuses in many member states - except for Finland, Ireland and the United Kingdom (Farkas, 2017).

$62.9 \%$ of migrants had no healthcare coverage or access to healthcare services at all, $15.2 \%$ had been denied care at least once, $4.5 \%$ had experienced racism in a healthcare setting, and as a result $20.4 \%$ had given up seeking medical care altogether.

The Roma, Europe's largest ethnic minority group (with approximately twelve million members), live in all European countries. In most cases, they live in segregated areas or settlements without proper access to healthcare services or proper health coverage in general (Kühlbrandt et al., 2014). Undocumented migrants prefer to contact medical staff only if they have failed to find another solution within their networks. They have financial commitments to their families back home, and so these groups do not have the privilege of being able to self-isolate.

Scientific evidence (Access to healthcare in Europe..., 2012) shows that migrants (particularly undocumented ones) prefer to stay invisible to the health authorities due to administrative issues $(21.9 \%)$, financial matters (27.9\%), language barriers, fear of getting deported (52\%), or because they lack knowledge or understanding of the health system and their rights (14.1\%). Due to the pandemic, they are now at an increased risk - as most of them live without access to clean water. Also, a Covid-19 symptomatic migrant will rather not seek medical help due to distrust of health workers and in order to avoid institutional discrimination.
The social determinants of health are mostly responsible for health inequities (Marmot et al., 2012), which can be defined as differences in health status or as the distribution of health determinants between different population groups (Constitution of the WHO, 1946). Most studies on the access to healthcare services for undocumented migrants show that migrants without legal entitlement face difficulties when accessing healthcare services other than emergency care services (Dauvrin et al., 2012).

Legal entitlements for migrant EU Roma citizens do not differ within EU countries, but they vary significantly for undocumented migrants Europe-wide - and in many countries there seems to be a mismatch between theoretical legal entitlements for undocumented migrants and their implementation in practice. A research study (European Agency for Fundamental Rights, 2016) in 28 member states on the right of access to health care for undocumented migrants found that undocumented migrants only have the right to free healthcare above emergency care level in five countries (BE, FR, NL, PT, UK), and Italy provided undocumented migrants with partially free healthcare services. As of 2018 Spain has been providing everyone, including undocumented migrants, with universal health coverage, while in Germany undocumented migrants do not have full access to healthcare services, about which in 2019 the UN Committee on Economic Social and Cultural Rights expressed its concerns.

European migrant health policies are seemingly well structured and responsive to the needs of migrants. However, the question is whether these legislations are responsive enough to the needs of migrants, especially now, during the pandemic. Although some governments provide new migrants with language courses, undocumented migrants are not entitled to benefit from them - as they remain invisible to the authorities. This results in a group of undocumented migrants who do not speak the language of their host country. It also raises concerns in relation to whether their understanding of the precautionary measures that will prevent them from becoming infected is sufficient enough. In general, the Roma have a low level of health literacy (Manhalova and Rolantova, 2018; Stoynovska et al., 2018), which makes them even more vulnerable during a pandemic. The question arises as to whether

\footnotetext{
* Author for correspondence: Bernadett de Varga, Public Health Adviser - Migrants \& Ethnic Minorities, Candidate of the United Nations Human Rights Council Special Rapporteur on the right to health mandate, 2020, former Scientific Collaborator of the Université Catholique de Louvain, Belgium; e-mail: bmvarga@icloud.com; http://doi.org/10.32725/kont.2020.024

Submitted: 2020-06-19 • Accepted: 2020-07-03 • Prepublished online: 2020-07-28
} 
they are able to fully understand how the virus transmits or how they can protect themselves from it. In general, they are not very aware of their fundamental right to healthcare, and lack information both on the health system and their rights (Kühlbrandt et al., 2014).

The right to healthcare is a fundamental right and it should be universally applied. Access to healthcare services should be available to every human being - regardless of race, religion or other criteria, including legal status. Article 12 of the International Covenant on Economic, Social and Cultural Rights states the "right of everyone to enjoy the highest attainable standard of physical and mental health". Later, this was recognized by the European Convention for the Protection of $\mathrm{Hu}-$ man Rights and Fundamental Freedoms of the Council of Europe and the European Social Charter - adopted in 1961 and revised in 1996 (Rechel et al., 2013). According to the Tallinn Charter (2008), there is a difference between accessibility and entitlement. Accessibility relates to the provision of a service, while entitlement is about financing and stewardship.

In theory, the migrants' legal entitlement to access health care is sufficient and satisfactory, but in practice these migrants face difficulties, prejudice, discrimination and other barriers when approaching health services. It is therefore our responsibility to adapt our health systems to allow for diversity, and we must also ensure that these vulnerable groups obtain adequate information in relation to the pandemic.

\section{References}

1. Access to healthcare in Europe in times of crisis and rising xenophobia (2012). An overview of the situation of people excluded from healthcare systems. [online] [cit. 2020-04-20]. Available from: https://www.uems.eu/_data/assets/pdf_ file/0009/1530/MdM_Report_access_healthcare_in_times_of_ crisis_and_rising_xenophobia.pdf

2. Chauvin P, Simonnot N, Vanbiervliet F, Vicart M, Vuillermoz C (2015). Access to healthcare for peoplefacing multiple vulnerabilities in healthin 26 cities across 11 countries. Report on the social and medical data gathered in 2014 in nineEuropean countries, Turkey and Canada. Paris: Doctors of the World - Médecins du monde international network. [online] [cit. 2020-04-20]. Available from: https://mdmeuroblog.files. wordpress.com/2014/05/mdm-intl-network-full-report-11countries-18th-may-2015.pdf
3. Constitution of the World Health Organization (1946). [online] [cit. 2020-06-22]. Available from: https://apps.who.int/gb/bd/ $\mathrm{PDF} / \mathrm{bd} 47 / \mathrm{EN} /$ constitution-en.pdf?ua $=1$

4. Dauvrin M, Lorant V, Sandhu S, Devillé W, Dia H, Dias S, et al. (2012). Health Care for Irregular Migrants: Pragmatism Across Europe: A Qualitative Study. BMC Res Notes 5: 99. DOI: 10.1186/1756-0500-5-99.

5. Directive 95/46/EC of the European Parliament and of the Council of 24 October 1995 on the protection of individuals with regard to the processing of personal data and on the free movement of such data (1995). Official Journal of the European Communities No. L 281/31. [online] [cit. 2020-06-22]. Available from: https://eur-lex.europa.eu/legal-content/EN/TXT/ $\mathrm{PDF} /$ ?uri=CELEX:31995L0046\&from $=\mathrm{en}$

6. European Agency for Fundamental Rights (2016). Healthcare entitlements of migrants in an irregular situation in the EU-28. [online] [cit. 2020-04-20]. Available from: https://fra.europa. eu/en/publication/2016/healthcare-entitlements-migrantsirregular-situation-eu-28

7. Farkas L (2017). Data collection in the field of ethnicity. Analysis and comparative review of equality data collection practices in the European Union. Directorate-General for Justice and Consumers.

8. Kühlbrandt Ch, Footman K, Rechel B, McKee M (2014). An examination of Roma health insurance status in Central and Eastern Europe. European Journal of Public Health 24(5): 707-712. DOI: 10.1093/eurpub/cku004.

9. Manhalova J, Rolantova L (2018). Aspects of health literacy in the Roma population and the co-operation of nursing. SGEM Scientific eLibrary. DOI: 10.5593/sgemsocial2018H/31/ S13.073.

10. Marmot M, Allen J, Bell R, Bloomer E, Goldblatt P, on behalf of the Consortium for the European Review of Social Determinants of Health and the Health Divide (2012). WHO European Review of Social Determinants of Health and the Health Divide. Lancet 380(9846): 1011-1029. DOI: 10.1016/ S0140-6736(12)61228-8.

11. Rechel B, Mladovsky P, Ingleby D, Mackenbach JP, McKee M (2013). Migration and health in an increasingly diverse Europe. Lancet 381: 1235-1245. DOI: 10.1016/S0140-6736(12)620868

12. Stoynovska M, Karcheva M, Petrov G, Borisov G (2018). Focus on health literacy, lifestyle, and health care of Roma population in Pleven region, Bulgaria. European Journal of Public Health 28(Suppl. 4). DOI: 10.1093/eurpub/cky218.173.

13. Tallinn Charter: "Health Systems for Health and Wealth" (2008).World Health Organization. [online] [cit. 2020-06-22]. Available from: https://www.euro.who.int/en/publications/ policy-documents/tallinn-charter-health-systems-for-healthand-wealth 